\title{
INFECTION OF BURNS*
}

BY

E. J. L. LOWBURY, M.A., D.M.

M.R.C. Industrial Injuries and Burns Research Unit, Birmingham Accident Hospital

Compared with the specific fevers and with any infection that arises in healthy tissue, infection of burns presents a confused picture. This is due to various factors, the most obvious being our difficulty in telling which pathological changes are caused by infection and which are caused by the initial trauma itself. Confusion also arises from the fact that many burns heal well even when heavily colonized by bacteria; moreover, mixed rather than pure cultures are isolated from most burns, and for this reason it may be hard or impossible to recognize which bacteria are to blame for a manifest infection. While there is no dispute about the pathogenicity of Streptococcus pyogenes, other organismsfor example, Pseudomonas pyocyanea - have been regarded as pathogens of greater or less significance, dismissed as saprophytes, and sometimes even welcomed as allies against the more obvious enemy.

Clinical accounts of infection can be clearly recognized in the earlier literature on burns. Fabricius (1607) speaks of an ulcus profundum et putridum after the separation of burn slough; Dupuytren (1833) found abundant suppuration, fever, wasting, and death in patients with deep burns even when they were not extensive; and Bird (1855) said of the fever and inflammation in burned patients that they were not essentially different from such symptoms after other kinds of injury. Lister was aware of these infections, but unlike some of his contemporaries-for example, Pirrie (1867) and Maylard (1892)-he made no serious attempt to extend his antiseptic discipline to the treatment of burns-probably because the defence of burns against contamination was assumed to be an impossible objective (Lister, 1909; Dunbar, 1934).

Local and general injury by bacteria colonizing burns was recognized by various authors-for example, Lustgarten (1891) and Stockis (1903) - but the detailed study of burn flora was not undertaken until many years later. In 1926 Pack reported that practically every burn becomes contaminated within a few hours, the commonest organisms present being streptococci, staphylococci, and Ps. pyocyanea. These findings were extended by Aldrich (1933) and by Cruickshank (1935). who attributed the "toxaemia" and fever often found on the second and third days after burning injuries to septic infection of the burned surface. These authors and Wilson et al. (1938) emphasized the importance of streptococci: Marsh (1935) and Heggie and Heggie (1942) regarded Staphylococcus aureus as an important pathogen of burns. In the United States, Langohr et al. (1947), reporting a detailed bacteriological study of the burned surface, considered haemolytic streptococci and staphylococci particularly damaging to deep burns, the latter especially when present together with organisms of the Proteus group.

The work initiated by Colebrook in Glasgow (Colebrook et al., 1944) and carried on by him and later by his collaborators at the Birmingham Accident Hospital has been concerned primarily with the protection of burns against infective organisms; it has *Lecture given at the Postgraduate Medical School, Hammersmith Hospital, on May 6, 1959. been supported by studies on the epidemiology and chemotherapy of these infections, the pathogenicity of the bacteria, and the natural defences which the body puts up against them.

\section{Bacterial Flora of Burns \\ Techniques}

In our studies on hospital in-patients (between 300 and 400 a year) we have used swabs moistened with $10 \%$ broth in physiological saline for sampling the burn surface on admission, at every change of dressings, at operations, and daily if the burn is treated by the exposure method. The swabs are inoculated on horseblood agar (containing 4 to $6 \%$ agar to prevent the swarming of proteus) and in cooked-meat broth, which is subcultured after overnight incubation at $37^{\circ} \mathrm{C}$. to blood agar and to a selective medium for $P$ s. pyocyanea (Lowbury and Collins, 1955). All colony types are examined for morphology in Gram-stained films, and various confirmatory tests are made-a tube coagulase test for Staph. aureus, grouping of streptococci by Lancefield's method, examination for pigments of Ps. pyocyanea (Lowbury, 1951), urease tests for proteus (Cook, 1948), and, at certain times, biochemical tests for the classification of coliform bacilli (Report, 1956). For limited periods, too, we have examined burn swabs for the presence of Clostridium welchii and Cl. tetani (Lowbury and Lilly, 1958a, 1958b), and for anaerobic cocci by the method of Thomas and Hare (1954). Other examinations included in this study are the serological typing of many strains of Str. pyogenes and Ps. pyocyanea, phage-typing of Staph. aureus, and sensitivity tests by a ditch-plate method with appropriate antibiotics, especially for Staph. aureus and Str. pyogenes.

The patients are treated in two open wards, with limited cubicle isolation space in one of them. Burns which are treated by the "closed" method are dressed by a no-touch technique in a plenum-ventilated dressing-station (Bourdillon and Colebrook, 1946), supported by various other methods of combating cross-infection, including the oiling of floors and blankets (more recently the use of cotton cellular blankets) and isolation of patients with streptococcal infections (see Colebrook, 1950).

Observations
The bacteria which are isolated from burns by these methods vary with the time since injury, the area of the burn, the place where the patient is being treated, and the type of treatment given.

A typical bacteriological record of the burn of a patient during the period of hospital treatment is shown in Table I. The skin bacteria are killed at the time of burning, and swabs taken shortly afterwards are sterile or very sparsely contaminated. After 24 hours a variety of organisms will be found growing in all but the most superficial burns and in some of those-for example on hands and feet-which are protected by good cover (see example in Table II). During the first two to three weeks Gram-negative bacilli, including $P s$. pyocyanea and proteus, are apt to predominate, accompanied by Staph. aureus, micrococci, Str. faecalis, diphtheroid bacilli, and aerobic spore-bearing bacilli in various combinations. Str. pyogenes is sometimes common, and at other times is absent from the wards for lcng periods. Anaerobic cocci are relatively rare and also tend to be absent for long periods. In the later 
TABLE I.-Bacteria Isolated from Burns (Example). Deep and Partial-thickness Burns of Hands and Face, both Legs, and Perineum ; Estimated Area, 15\% (Imperfect Coler)

\begin{tabular}{|c|c|c|c|c|c|c|c|c|c|c|c|}
\hline \multirow{2}{*}{ Burn Site } & \multirow{2}{*}{ Bacteria on Burn } & \multirow{2}{*}{ On Admission } & \multicolumn{9}{|c|}{ During Weeks } \\
\hline & & & 1 & 2 & 3 & 4 & 5 & 6 & 7 & 8 & 9 \\
\hline Right thigh & $\begin{array}{l}\text { Strep. Gp. A } \\
\text { Staph. aureus } \\
\text { Ps. pyocyanea } \\
\text { Coliforms .. } \\
\text { Others } \quad \text {.. }\end{array}$ & $\begin{array}{l}0 \\
0 \\
0 \\
0 \\
+ \\
=\end{array}$ & $\begin{array}{c}0 \\
+ \\
\vdots \\
0 \\
+++ \\
0\end{array}$ & $\begin{array}{c}0 \\
0 \\
+++ \\
0 \\
0\end{array}$ & $\begin{array}{c}0 \\
+++ \\
+++ \\
+ \\
0 \\
=\end{array}$ & $\begin{array}{l}0 \\
+ \\
+ \\
+ \\
+ \\
0\end{array}$ & $\begin{array}{c}0 \\
+++ \\
++ \\
+++ \\
0\end{array}$ & $\begin{array}{c}0 \\
+++ \\
+ \\
+\underset{+}{\Rightarrow}+ \\
0\end{array}$ & $\begin{array}{c}0 \\
++ \\
+ \\
+ \\
++ \\
0\end{array}$ & $\begin{array}{c}0 \\
+++ \\
+ \\
+ \\
+ \\
0\end{array}$ & $\begin{array}{c}0 \\
++ \\
+ \\
+ \\
+ \\
+\end{array}$ \\
\hline Local treatm & $\cdots$ & \multicolumn{3}{|c|}{$\begin{array}{l}\text { Dressings } \\
\text { (penicillin cream) }\end{array}$} & $\begin{array}{c}{ }_{(85 \%} \text { Otake }^{n} \\
\left(85 \text { take }^{n}\right.\end{array}$ & \multicolumn{2}{|c|}{$\begin{array}{l}\text { Dressings } \\
\quad \text { (tulle gras) }\end{array}$} & \multicolumn{2}{|c|}{$\bigoplus_{(55 \% \text { take) }}^{\uparrow}$} & $\begin{array}{c}\uparrow \\
\text { Exposed }\end{array}$ & \\
\hline
\end{tabular}

weeks after the separation of slough, Staph. aureus and (when it is about) Str. pyogenes tend to predominate in unhealed burns. Table III shows the time of the first appearance of various organisms in a series of burns; Str. pyogenes is conspicuous for its tendency to appear in the later stages, often in small unhealed areas.

The bacterial colonization of burns in hospital is an extreme example of what is generally called "hospital infection." The bacteria reflect the environment rather than the flora brought in by the patient on his skin and mucous membranes. Once or twice a year, for example, we have experienced an outbreak of infection with Str. pyogenes, which is often of one serological type. The staphylococci which we find in burns to-day (see Table IV) include a preponderance of strains belonging to phage group III and a fairly high

TABLE II.-Bacteria Isolated from Burns (Example). Deep and Partial-thickness Burns of Both Legs; Estimated Area, $5 \%$ (Good Cover)

\begin{tabular}{|c|c|c|c|c|c|c|c|c|}
\hline \multirow{2}{*}{$\begin{array}{l}\text { But:0 } \\
\text { Site }\end{array}$} & \multirow{2}{*}{$\begin{array}{l}\text { Bacteria } \\
\text { on Burn }\end{array}$} & \multirow{2}{*}{$\underset{\text { Admission }}{\text { On }}$} & \multicolumn{6}{|c|}{ During Weeks } \\
\hline & & & 1 & 2 & 3 & 4 & 5 & 6 \\
\hline $\begin{array}{c}\text { Left leg } \\
\text { (below } \\
\text { knee) }\end{array}$ & $\begin{array}{l}\text { Strep. Gp. A .. } \\
\text { Sirph. aureus .. } \\
\text { Ps. ;vocyanea } \\
\text { Colifurms .. } \\
\text { Others }\end{array}$ & $\begin{array}{l}0 \\
0 \\
0 \\
0 \\
0\end{array}$ & $\begin{array}{l}0 \\
0 \\
0 \\
0 \\
0\end{array}$ & $\begin{array}{l}0 \\
0 \\
0 \\
0 \\
0\end{array}$ & $\begin{array}{l}0 \\
0 \\
0 \\
0 \\
0\end{array}$ & $\begin{array}{l}0 \\
0 \\
0 \\
0 \\
+\end{array}$ & $\begin{array}{c}0 \\
T \\
=- \\
0 \\
0 \\
+-\end{array}$ & $\begin{array}{l}0 \\
0 \\
0 \\
0 \\
++\end{array}$ \\
\hline \multicolumn{2}{|c|}{ Local treatment } & \multicolumn{7}{|c|}{ 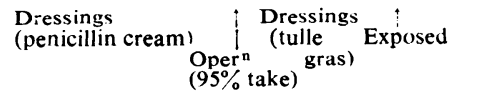 } \\
\hline
\end{tabular}

TABLE III.-First Appearance of Bacteria on Fresh Burns

\begin{tabular}{|c|c|c|c|c|c|}
\hline Organism & $\begin{array}{c}\text { Ist Week } \\
(\%)\end{array}$ & $\begin{array}{c}\text { 2nd Week } \\
(\%)\end{array}$ & $\begin{array}{c}\text { 3rd Week } \\
(\%)\end{array}$ & $\begin{array}{l}\text { Later } \\
(\%)\end{array}$ & $\begin{array}{c}\text { Total } \\
\text { Infections }\end{array}$ \\
\hline $\begin{array}{l}\text { Str. pyogenes .. } \\
\text { Staph. aureus .. } \\
\text { Ps. pyocyanea } \\
\text { Proteus } \\
\text { Coliform bacilli }\end{array}$ & $\begin{array}{l}21 \\
76 \\
54 \\
38 \\
68\end{array}$ & $\begin{array}{l}25 \\
18 \\
30 \\
36 \\
21\end{array}$ & $\begin{array}{l}4 \\
2 \cdot 5 \\
10 \\
19 \\
10\end{array}$ & $\begin{array}{l}50 \\
3 \cdot 5 \\
6 \\
7 \\
1\end{array}$ & $\begin{array}{r}24 \\
115 \\
63 \\
74 \\
90\end{array}$ \\
\hline
\end{tabular}

TABLE IV.-Phage Groups of Staph. aureus in Birmingham

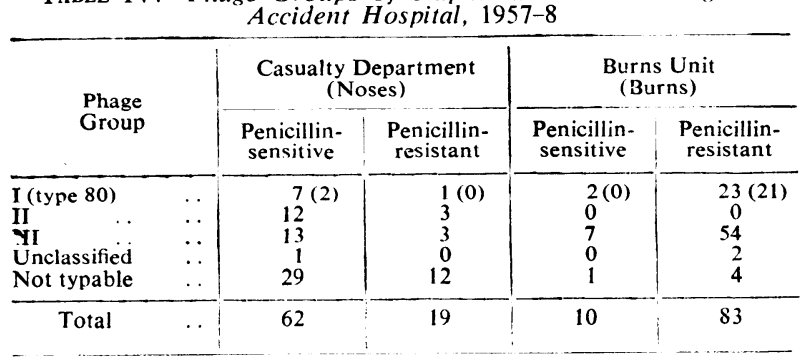

proportion of group I (type 80) strains; from 80 to $100 \%$ are resistant to penicillin, and a large proportion are also resistant to the tetracyclines and to erythromycin. The Gram-negative bacilli are also different in various ways from the alimentary flora, and are clearly acquired by cross-infection ; Ps. pyocyanea, for example, is very common in burns, especially if they are extensive, but it appears in only about $3 \%$ or less of normal stools (Sevitt, 1945 ; Lowbury and Fox, 1954). Strains of Proteus and of Klebsiella are also common in burns ; faecal Escherichia coli, on the other hand, is at times among the less-frequent coliforms of the burn flora.

The burned tissue forms a slough which usually separates in two to three weeks. While it occupies the site of injury, the slough is a hospitable medium for many bacteria, especially Gram-negative bacilli, where they can multiply relatively undisturbed by the natural defences and protected against antibiotics. After the slough has separated, the surface of the burn consists of granulation tissue on which Str. pyogenes and Staph. aureus flourish, but the Gram-negative bacilli, which grow less well in fresh serum, appear to be at a disadvantage; hence the preponderance of Grampositive cocci at this stage.

The larger the area of the burn and the longer it remains unhealed, the greater is the likelihood of colonization by pathogenic organisms, such as $P s$. pyocyanea, and also by relatively ..ansient saprophytes, such as $\mathrm{Cl}$. welchii. Cl. tetani was not found in a series of 273 swabs from burns, and there has been only one case of tetanus in an in-patient during the past 10 years.

\section{Prophylaxis}

Bacterial colonization may perhaps not interfere with healing of superficial burns, but it is desirable to prevent these from becoming a reservoir of pathogens which may infect patients in the ward with deeper burns. When the burns are of deep partial thickness and full skin thickness, prophylaxis is more directly important. For full-skin-thickness burns new skin is undoubtedly' the best defence against infection (Ross, 1950), but infection, if it appears first, is one of the worst enemies. of a new skin. For burns which cannot be excised and grafted on admission to hospital, therefore, other means of excluding bacteria are necessary.

Colebrook and his colleagues aimed to achieve not total asepsis but a selective shielding of burns from pathogens-and especially from Str. pyogenes-in the environment by the use, whenever possible, of ample dressings in layers of gauze, cotton-wool, and crêpe bandage. This physical barrier was supported by other 
methods, and in particular the following: (1) a " notouch" dressing technique (McKissock et al., 1941; Williams et al., 1944); (2) the use of a plenum-ventilated dressing-station; (3) the use of local prophylactic chemotherapy (with penicillin cream); and (4) chemotherapy and bed or cubicle isolation for known infections in the ward. The simultaneous application of these methods in Birmingham was associated with a lower incidence $(5 \%)$ of streptococcal infection than was found in Glasgow $(30 \%)$, where prophylactic penicillin cream and plenum ventilation were not used ; there was, however, no obvious reduction in the incidence of infection by Staph. aureus, Ps. pyocyanea, and proteus (Colebrook et al., 1948).

About 10 years ago we started a series of controlled trials to assess the relative merits of these and other techniques in protecting burns against colonization by pathogens. Patients eligible for inclusion in these trials were divided by random selection into two groups, one of which received the prophylactic treatment under investigation while the other was treated as a control series; details of treatment other than that under investigation were comparable in the two groups, and whenever possible the identity of the treatment and control groups was unknown to those who were treating the patients and analysing the results.

\section{Chemoprophylactic Trials}

Prophylaxis Against Str. pyogenes.-A trial of local penicillin prophylaxis was carried out on patients admitted to hospital with small or medium-sized burns which did not have immediate skin-grafting or require shock treatment (Jackson et al., 1951a). Patients in the treatment group had their burns dressed on admission and at every change of dressings with penicillin cream (mostly 1.000 units/g.), or sprayed, if they were exposed, with a penicillin solution; the control burns were dressed with the cream base, or sprayed with distilled water. Analysis of the results (see Fig. 1) showed that $1.7 \%$ of 58 burns treated with local penicillin application picked up Str. pyogenes, as compared with $38 \%$ of 42 burns in the control group.

Prophylaxis Against Ps. pyocyanea.-Preliminary studies with polymyxin $E$ showed that all strains of $P$ s. pyocyanea isolated in our unit were sensitive to the antibiotic, and appreciable increases in resistance did not occur on attempted habituation in vitro and during a prophylactic trial in burns (Jackson et al., 1951b). This trial was carried out in the same way as the trial with penicillin, except that, in this one, both treatment and control creams contained penicillin (1,000 units/g.), the treatment cream containing, in addition, polymyxin E (1 mg./g.); solutions were used for spraying the exposed burns. The results of this trial are also presented in Fig. 1. Out of 160 burns treated with polymyxin and initially free from $P s$. pyocyanea 11 (7\%) became colonized by the organism, as compared with 50 out of $207(24 \%)$ burns in the control series. There was a smaller but still significant difference in the proportions of added coliform bacilli in the two groups, but no difference in the proportions of Str. pyogenes or Staph. aureus, which are resistant to polymyxin.

Prophylaxis Against Staph. aureus.-The frequent carriage of Staph. aureus by normal subjects and the tendency of staphylococci to produce antibioticresistant variants frustrated our earlier attempts at

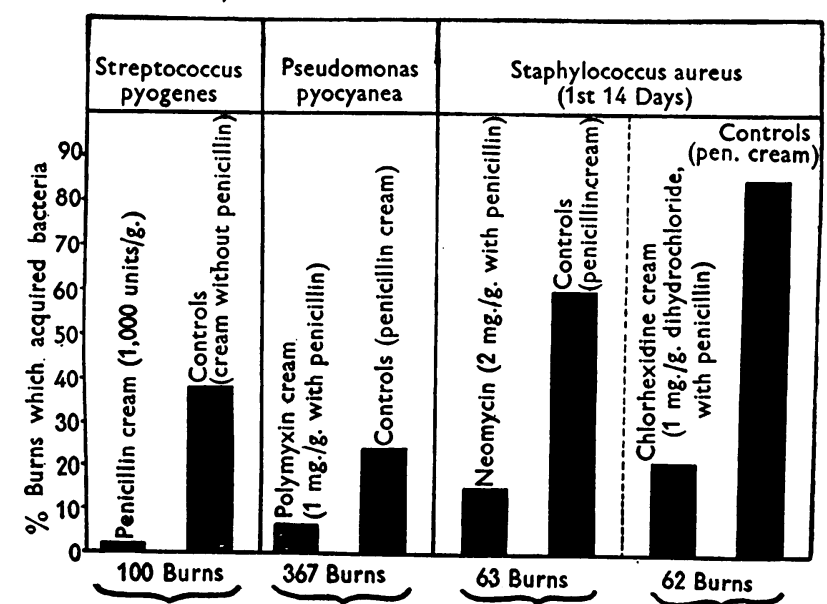

FIG. 1.-Bacteriological results of four controlled trials of local chemoprophylaxis directed against specific pathogens (see Jackson et al., 1951a, 1951b; Lowbury, 1955).

prophylaxis against these organisms. Successful prophylaxis with chlortetracycline, for example, was demonstrated in controlled trials when the antibiotic was new, but was not maintained on account of the appearance of resistant staphylococci which became predominant in the burns unit after a few months (Lowbury et al., 1952). On the other hand, the local application of neomycin, bacitracin, and chlorhexidine has not, in our experience, led to the emergence of resistant variants. Significant protection against added Staph. aureus (see Fig. 1) has been obtained in preliminary trials of local prophylaxis with creams containing neomycin (2 mg./g.) and chlorhexidine dihydrochloride (1 mg./g.) (Lowbury, 1955).

Combined Chemoprophylaxis.-In recent trials, which will be reported separately, the combined application of polymyxin, chlorhexidine, and neomycin has been found effective in prophylaxis; many burns remained apparently sterile, and added infection, with Staph. aureus in particular, was greatly reduced in the patients receiving this prophylactic cream.

\section{Physical Methods of Prophylaxis}

Plenum-ventilated Dressing-station

Bourdillon and Colebrook (1946) showed that the agitation of contaminated textiles-for example, removal of dressings - caused a build-up and a sustained high level of airborne bacteria, including wound pathogens, which could be prevented by plenum ventilation of the room. Using a plant that delivered 20 changes of filtered air per hour, they found that the numbers of airborne bacteria were negligible five minutes after the departure of a patient from the dressing-room. Another patient admitted at this stage could therefore be dressed in clean air.

In a controlled trial on patients with burns of small or moderate extent (Lowbury, 1954) it was shown that added infection of burns with Ps. pyocyanea, with antibiotic-resistant Staph. aureus, and with proteus was significantly lower in patients dressed in this room with the plenum plant working than in the control series whose dressings were changed by the same team in the same room, but without plenum ventilation (Fig. 2). Streptococcal infections were also consistently less common in patients dressed in the ventilated room, but coliform bacilli were evenly distributed in the two 


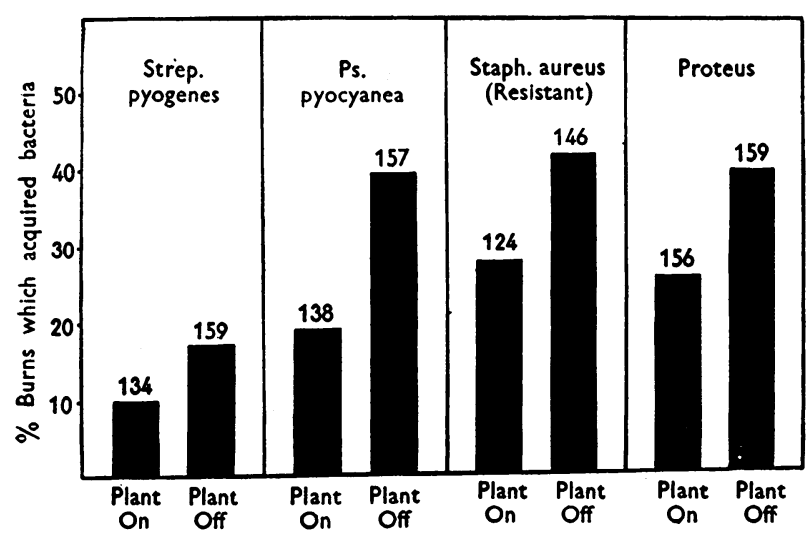

Fig. 2.-Bacteriological result of a controlled trial of plenumventilated dressing-station for burns (see Lowbury, 1954).

groups. As the patients spent a very small fraction of their hospital time in the dressing-station these differences are striking, especially in view of the opportunities for cross-infection that exist in the ward.

In a study on the serological types of Ps. pyocyanea (Lowbury and Fox, 1954) it was found that each ward had, for a time, its own predominant serotype of Ps. pyocyanea in spite of the shared dressing-room (Fig. 3). From this we may gather that cross-infection is also very common while the patient is lying in the ward. Air, floor dust, nurses' hands, and the bedding and bandages of patients are demonstrable reservoirs and vectors of these organisms. Burns treated by the exposure method or with imperfect cover are especially prone to contamination in the wards.

\section{Exposure Treatment versus Dressings}

It has been argued that a dry surface, such as that which forms over a burn exposed to the air, does not favour bacterial growth, and that the eschar protects the burn from contamination (Wallace, 1949 ; Blocker et al., 1951 ; Körlof, 1956). There are clinical advantages in treating burns of the face and certain trunk burns by the exposure method, but burns in these areas are, in fact, more apt to be colonized by Str. pyogenes,

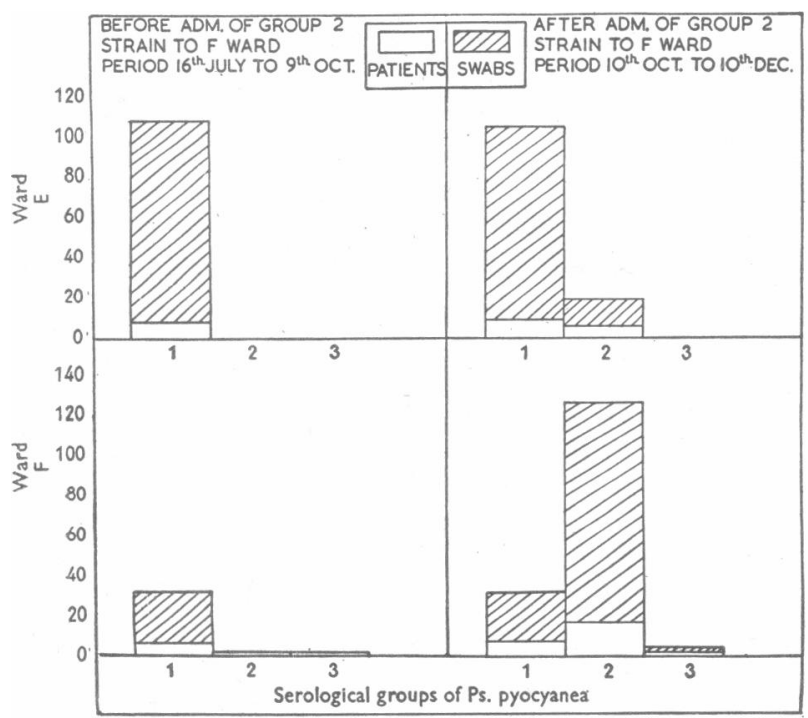

Fio. 3.-Illustration of cross-infection in a burns ward: after the admission of a patient with Ps. pyocyanea of serological group 2 to Ward F, that organism became predominant in Ward F only, though two wards shared the same dressing-station and operatingtheatre (see Lowbury and Fox, 1954).
Ps. pyocyanea, and other pathogens than burns of the hand and the foot, which can be satisfactorily covered with dressings (Table V). Moreover, the eschar, which often shows few bacteria on its outer surface, is apt to enclose a pool of pus (Lowbury et al., 1954).

The application of a cream under dressings facilitates the separation of slough and the use of local chemotherapy and prophylaxis ; local prophylaxis with powder on exposed areas is clearly not very effective, for penicillin-lactose powder was insufflated on to all the face burns in our series, which, as I have said, acquired Str. pyogenes more often than any other sites. On the other hand, the application of cream and dressings encourages the growth of those bacteria which can reach the burn and which are not suppressed by the antibiotic barrier; for example, Ps. pyocyanea grows in dressings soaked with exudate and produces there

TABle V.-Organisms Acquired by Burns on Different Parts of the Body (Admissions During 12 Months)

\begin{tabular}{|c|c|c|c|c|c|c|}
\hline \multicolumn{3}{|c|}{ Site of Burn } & \multirow{2}{*}{$\begin{array}{c}\begin{array}{c}\text { Str. } \\
\text { pyogenes } \\
\%+\end{array} \\
13.9 \\
6.1 \\
1.6 \\
9.9 \\
10.1 \\
13.7\end{array}$} & \multirow{2}{*}{$\begin{array}{c}\begin{array}{c}\text { Staph. } \\
\text { aureus } \\
\%+\end{array} \\
93 \\
55 \\
48 \\
83 \\
73 \\
85\end{array}$} & \multirow{2}{*}{$\begin{array}{c}\begin{array}{c}\text { Ps. } \\
\text { pyoocyanea } \\
\%+\end{array} \\
38 \\
20 \\
15 \\
48 \\
52 \\
50\end{array}$} & \multirow{2}{*}{$\begin{array}{c}\begin{array}{c}\text { Coliform } \\
\text { Bacilli } \\
\%+\end{array} \\
55 \\
27 \\
41 \\
63 \\
62 \\
76\end{array}$} \\
\hline $\begin{array}{l}\text { Face } \\
\text { Hands } \\
\text { Feet } \\
\text { Arms } \\
\text { Legs } \\
\text { Trunk }\end{array}$ & $\begin{array}{l}\cdots \\
\cdots \\
\cdots \\
\cdots\end{array}$ & $\begin{array}{l}\ldots \\
\cdots \\
\ldots \\
\cdots\end{array}$ & & & & \\
\hline Tota & ourns & & 732 & 571 & 691 & 650 \\
\hline
\end{tabular}

large amounts of the blue pigment pyocyanin, a powerful toxin for skin cells (see below). This mechanism may perhaps account for the findings of Holman et al. (1956), who describe quicker healing of experimental burns in pigs treated by exposure than under dressings. The problems raised by these findings require further study. From the existing data it seems that each method has advantages which are determined by the position of the burn, the climate, the patient's preference, and various details of treatment.

\section{Comments on Prophylaxis}

Each of the prophylactic measures we have tested contributes only a partial protection of the burns, and the best results may be expected from their combined use, preferably with others that we have not had an opportunity of testing-for example, cubicle isolation of all or most of the patients.

Chemoprophylaxis can be successfully maintained only if the organisms against which it is directed do not acquire resistance to the agent applied to the burn. This requirement is met by penicillin against Str. pyogenes, by bacitracin and chlorhexidine against Str. pyogenes and Staph. aureus, by neomycin against Staph. aureus, and by polymyxin against Ps. pyocyanea. Unfortunately, antibiotics which might be used for the systemic prophylaxis of burned patients are, with the exception of penicillin, likely to induce the selection of resistant variants, and no satisfactory local or systemic chemoprophylaxis exists against proteus and some other groups of Gram-negative bacilli.

\section{Pathogenicity of Burn Flora}

\section{Local Pathogenic Effects}

Inflammation at the margins of the burn, lymphadenitis, and lymphangitis are sometimes present, especially when streptococci of group A are growing 
in the burn; suppuration is very common, though not always easy to detect in exposed burns or to differentiate from residues of antibiotic cream in those treated with dressings. The most obvious criteria which can be measured are the results of skin-grafting operations and healing-times (cf. Bodenham, 1943; Clarkson and Lawrie, 1946). It is easy to show a direct association both of prolonged healing-time and of graft failure with higher frequency of Str. pyogenes, Ps. pyocyanea, and other organisms on burns of full skin thickness. Further evidence, however, is required before these bacteria can be stigmatized as the cause of such adverse effects, for it is certain that burns which take a longer time to heal also stand a greater chance of picking up these bacteria.

The evidence has come from trials in which bacteria have been excluded or eliminated from some of the burns by antibiotic therapy. In a trial of chlortetracycline for the treatment of Str. pyogenes infection, for example (Fig. 4), it was found that all but 2 out of 18 grafts "failed"-that is, showed less than $80 \%$ take-when the streptococcal infection was not adequately treated before operation, but only 11 out of 44 grafts failed when successful chemotherapy was used (Lowbury and Cason, 1954). In the controlled trial of polymyxin described above, grafting results were significantly better and the healing-time of burns of full skin thickness was significantly (on the average three weeks) shorter in the series protected with polymyxin (Fig. 5). Similarly, the use of successful chemotherapy or prophylaxis against Staph. aureus has been found to improve the results of skin-grafting (Lowbury, 1957).

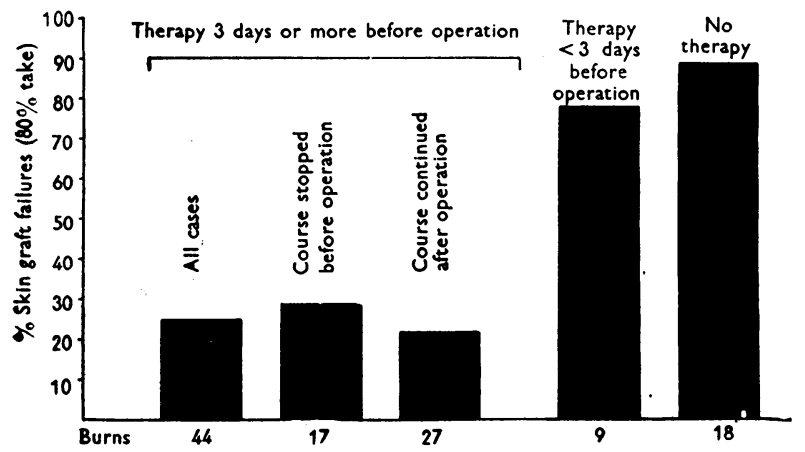

FIG. 4.-Effect of oral chlortetracycline against Str. pyogenes on the results of skin-grafting (see Lowbury and Cason, 1954).

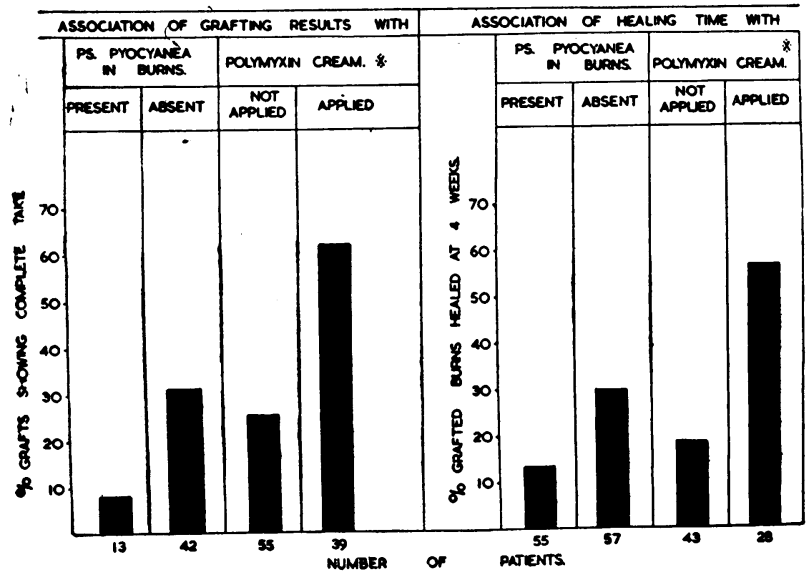

Fio. 5.-Influence of Ps. pyocyanea and of topical chemoprophylaxis on skin-grafting and on healing-time. When more than one grafting operation was required for any burn the worst result only is recorded in the assessment (see Jackson et al., result only is recorded in the assessi
$1951 \mathrm{~b})$.
The mechanism by which bacteria cause these adverse local effects has received some attention. In the case of Ps. pyocyanea the pigment pyocyanin has been shown to cause necrosis and to inactivate respiration of human skin-tissue culteres in concentrations much lower than those which are estimated to be present in green burn exudate (Cruickshank and Lowbury, 1953 ; Lawrence, 1958). Staphylococcal $\alpha$-toxin has been shown, by Dr. Lawrence in our unit, to have a similar effect on skin cells, but the toxin could not be detected in exudate on dressings over burns heavily colonized by Staph. aureus (Lawrence, 1959). How Str. pyogenes causes still greater damage to skin grafts has not been fully explored. Lawrence (1959) has shown that streptolysin $\mathrm{O}$ inhibits the respiration of $\mathrm{s}^{\prime}$ in cells. It has been suggested that streptokinase is of particular importance, as it is likely to prevent attachment of skin grafts to the receptor tissues; other factors, however, must also be involved, for streptococci of group $\mathrm{C}$ are often found in burns without causing graft failure, in spite of their production of abundant streptokinase.

\section{General Pathogenic Effects}

Str. pyogenes was formerly a common cause of septicaemia ; Cruickshank (1935), for example, reported its isolation at necropsy from the spleen of three out of six patients with streptococci in their burns. The picture has changed since the introduction of the sulphonamides and penicillin. For many years we have not seen any cases of Str. pyogenes septicaemia in the Birmingham Burns Unit : other burn organisms, however, are often found (sometimes in enormous numbers) in the blood of severely burned patients. Fs. pyocyanea and Staph. aureus are probably the most dangerous and also the commonest invaders (Jackson et al., 1951b ; Liedberg et al., 1954). Liedberg and his colleagues reported septicaemia in 15 out of 35 fatal cases of burns. Mixed infections are common. Markley et al. (1957), in Lima, found that Ps. pyocyanea septicaemia was a common cause of death in patients with extensive burns.

Str. pyogenes infection, even in quite small burns, is commonly associated with fever, sometimes after an apyrexial period-for example, Fig. 6. Pyrexia and hyperpyrexia in severely burned patients without demonstrable septicaemia may be due to bronchopneumonia or, more rarely, to meningitis or pyelonephritis ; but the local infection of an extensive burn by Gram-negative bacilli, staphylococci, and other organisms can probably cause pyrexial reactions and contribute to the severe general illness of these patients. In the trial of prophylaxis by polymyxin there was a consistently lower frequency of pyrexia, anaemia, and death in those who received the prophylaxis than in the controls-presumably through the exclusion of Ps. pyocyanea and other polymyxin-sensitive organisms. The presence of Döhle bodies in the leucocytes of the more extensively burned patients (Weiner and Topley, 1955) may also, perhaps, be the result of infection.

Bull and Fisher (1954) found little improvement in the mortality results from burns after the period 1942-7 in spite of advances in treatment. In the later series, however, there was a longer period of survival of all but the most severely burned patients, and those who were saved during the shock phase were likely to die later from other complications. Of these, infection was the most important, and of the infective agents $P$ s. pyocyanea 


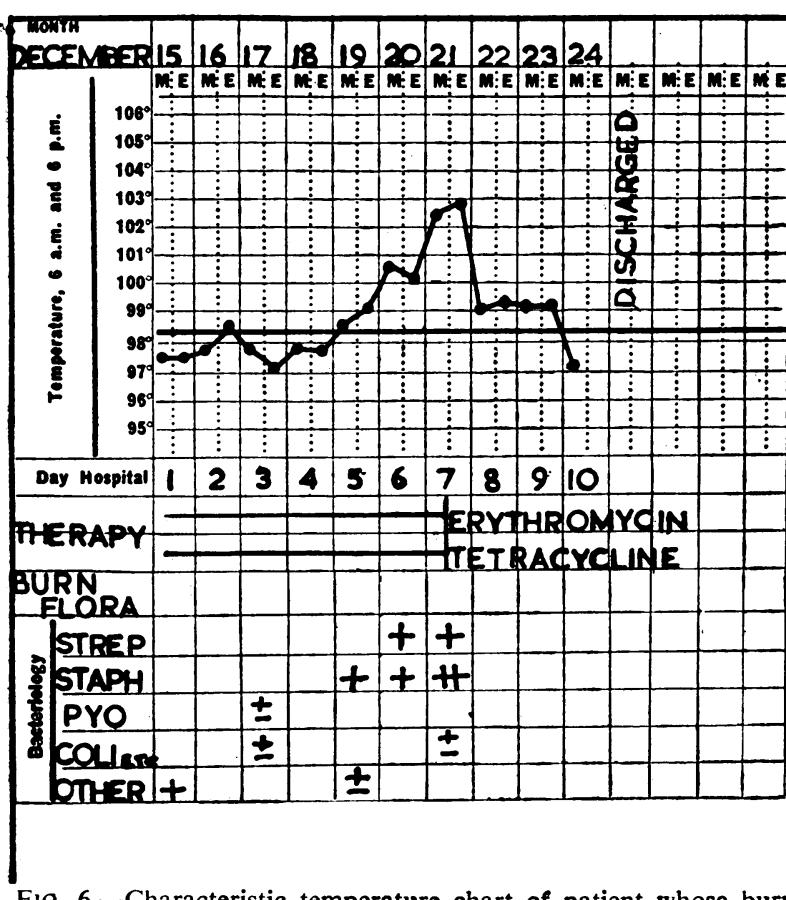

F10. 6.-Characteristic temperature chart of patient whose burn (of face only) became infected with Str. pyogenes.

has been most commonly associated with fatal septicaemia and bronchopneumonia in the same environment (Jackson et al., 1951b).

\section{Chemotherapy \\ Local Infections}

By good fortune Str. pyogenes, the organism which causes the worst local effects, is the one most easily eliminated by chemotherapy (Fig. 7). Application of a cream containing 10,000 units of penicillin per gramme (Jackson et al., 1951a) and of chloramphenicol (Liedberg et al., 1955) have been found effective. Penicillin applied in lower concentrations or given systemically has in recent years proved unsuccessful in eliminating or even excluding Str. pyogenes, apparently because penicillinase-producing organisms are almost always

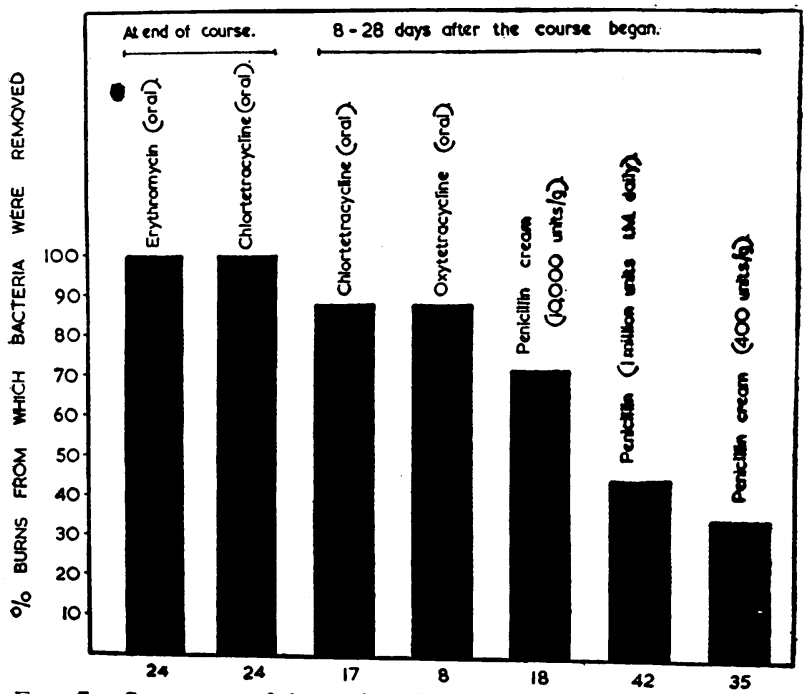

FIG. 7.-Summary of bacteriological results in trials of chemotherapy for infection by Str. pyogenes (see Jackson et al., 1951a; Lowbury and Cason, 1954). found in the same burns (Cruickshank et al., 1948 ; Jackson et al., 1951b ; Körlof, 1954).

For this reason, and because Str. pyogenes appears most commonly in burns which are best treated without dressings, oral tetracycline and erythromycin have proved to be the most convenient antibiotics for the treatment of streptococcal infection of burns, which they will almost invariably clear of the streptococci in three days (Lowbury and Cason, 1954). Unfortunately, tetracycline-resistant streptococci of group A may emerge and become endemic in an environment where the drug is much used for the treatment of streptococcal infections (Lowbury, 1958). Erythromycin-resistance has also been encountered on a few occasions. For this reason it may be desirable to use the combination of erythromycin and tetracycline for hospital treatment of streptococcal burns.

Sensitive staphylococci can usually be eliminated from covered burns by combined therapy with novobiocin and erythromycin (Lowbury, 1957). Except when there is evidence of staphylococcal sepsis, however, the clinical advantage of removing staphylococci is probably outweighed by the risks of inducing the emergence of doubly resistant staphylococci ; in burns treated by the exposure method this combined therapy is ineffective and resistance is especially prone to appear. Local application of chloramphenicol cream $(10 \mathrm{mg}$./g.) has been shown to have some therapeutic value against Staph. aureus, and polymyxin cream $(1 \mathrm{mg} . / \mathrm{g}$.$) can$ sometimes clear Ps. pyocyanea from a burn (Jackson et al., 1951b) ; these measures may be found useful in selected cases of clinical infection.

\section{General Infection}

Burn septicaemia is notoriously resistant to treatment. The organisms (especially the Gram-negative bacilli) are often resistant to most or all of the available antibiotics, but even when they are sensitive therapy commonly fails (Liedberg et al., 1954). This is probably due to the fact that the burns are not cleared of the infective bacteria and the blood is continuously reinfected from this source. Staphylococcal suppurative thrombophlebitis has been successfully treated with chlortetracycline when the organisms were sensitive (Jackson, 1951). To-day the staphylococci that infect burns in hospital are usually resistant to the tetracyclines, and the readiness with which they acquire resistance to erythromycin and novobiocin makes these antibiotic, uncertain therapeutic agents against staphylococcal infections of extensive burns. Fortunately, resistance of Staph. aureus to vancomycin has not been reported, and our initial experience of its use in staphylococcal septicaemia has been most promising (see also Davis et al., 1958 ; Dutton and Elmes, 1959).

\section{Natural Defences}

Viable tissues have considerable powers of resistance against bacterial infection. Phagocytes, non-specific bactericidal agents, antibodies, complement, and other features of a "micro-environment inimical to the infectious agent" (Dubos, 1955) are recognized components of this defence mechanism. Meleney (1948) thought that serological immunity has little if any value in the protection of wounds against streptococci staphylococci, proteus, Ps. pyocyanea, and other bacteria. Langhor et al. (1947), on the other hand, thought that an immune response to Staph. aureus contributed 
towards the healing of burns. We found a raised serum agglutinin titre to the serotypes of $P S$. pyocyanea in burns, the titre of agglutinins varying directly with the area of the burn and the duration of colonization with Ps. pyocyanea (Fox and Lowbury, 1953a). Rabbits immunized with these organisms gave smaller skin reactions on intradermal injection of the immunizing strains of Ps. pyocyanea than when Ps. pyocyanea of other serotypes were injected; there was evidence, too, of specific opsonizing activity by immune sera against the homologous $P$ s. pyocyanea (Fox and Lowbury, 1953b). Even if antibodies fail to remove bacteria from burns, they may perhaps have some value in preventing the organisms from spreading through intact tissue and invading the blood-stream. This view is supported by the association of septicaemia with reduced plasma gamma-globulin levels found in a recent trial (to be reported later).

There has been renewed interest in non-specific resistance in the past few years since the description by Pillemer et al. (1954) and Wardlaw and Pillemer (1956) of the properdin system. This bactericidal mechanism of normal serum operates in the presence of complement against a variety of organisms. Staph. aureus and Str. pyogenes are not sensitive to the properdin system; Gram-negative bacilli are often sensitive to it, but the types of Gram-negative bacilli commonly found in burns (Ps. pyocyanea and the Proteus and Klebsiella groups) are in our experience often resistant or slightly sensitive, in contrast with the intestinal $E$. coli, which are more often highly sensitive. Though properdin and complement titres are reduced in the serum of severely burned patients, the bactericidal activity of the serum against organisms sensitive to the properdin system is usually unaffected. It is clear that the value of this mechanism is very limited in the defence of the patient against the burn flora, though it may play some part in the selection of this flora (Lowbury and Ricketts, 1957 ; Willers, 1958).

The shortcomings of chemoprophylaxis and chemotherapy for infection of burns have prompted a renewal of interest in applying the principles of immunity. Rosenthal et al. (1957) have found that injection of gamma-globulin protects mice rendered highly susceptible to Ps. pyocyanea by burning or by cortisone. It is possible that the addition of gamma-globulin to the infusion fluid might help severely burned patients to resist invasion by an organism such as $P$ s. pyocyanea at the time when they are most susceptible to such infection.

\section{Conclusions}

Bacteria growing in deep burns can cause both local and general damage. Str. pyogenes, which has been reduced to negligible importance in other fields of surgery, is still the most formidable of the local burn pathogens, causing skin-graft failure, delayed healing, and deformity if it is not removed from the burn. Ps. pyocyanea, Staph. aureus, proteus, and other bacteria can sometimes also cause local damage, and are to-day more important as the cause of septicaemia and fatal infection than Str. pyogenes.

It has proved possible to keep a proportion of the burns free from Str. pyogenes, Staph. aureus, Ps. pyocyanea, and some of the coliform bacilli by a combination of physical and local chemotherapeutic barriers. Though the protection thus afforded is imperfect, it has proved clinically valuable. There is a dilemma involved in the choice between encouraging the formation of a dry adherent crust and using chemoprophylactic creams which keep the burn moist; when the former method is used, pathogens appear more frequently but perhaps cause less damage than they do when they can multiply not only in the burn but also in wet dressings. Future studies will include an attempt to combine the advantages of a relatively dry surface and of chemoprophylactic cover.

Another dilemma arises from the fact that the risks of infection are greater in burns units than when burned patients are nursed in general wards, though the facilities for expert treatment and research make burns units highly desirable in every other respect. It is probable that this dilemma can be solved by the development of units built and staffed with the aim of preventing crossinfection. The importance of protecting the burn surface from hospital flora must be emphasized, because the attempted prophylaxis of the patient by systemic antibiotics has proved disappointing, and routine therapy for established infection is impracticable or relatively ineffective except against Str. pyogenes.

\section{REFERENCES}

Aldrich, R. H. (1933). New Engl. J. Med., 208, 299.

Bird, J. (1855). Lancet, 2, 487.

Blocker, T. G., Blocker, V., Lewis, S. R., and Snyder, C. C (1951). Ann. Surg., 134, 574.

Bodenham, D C. (1943) Lancet, 2, 725

Bourdillon, R. B., and Colebrook, L. (1946). Ibid., 1, 561, 601.

Bull, J. P., and Fisher, A. J. (1954). Ann. Surg., 139, 269.

Clarkson, P., and Lawrie, R. S. (1946). Brit. J. Surg., 33, 311.

Colebrook, L. (1950). A New Approach to the Treatment of Burns and Scalds. Fine Technical Publications, London. Duncan, J. M., and Ross, W. P. D. (1948). Lancet, 1, 893. - Gibson, T., Todd, J. P., Clark, A. M., Brown, A.. and Anderson, A. B. (1944). Spec. Rep. Ser. med. Res. Coun (Lond.), No. 249.

Cook, G. T. (1948). J. Path. Bact., 60, 171

Cruickshank, C. N. D., and Lowbury, E. J. L. (1953). Brit. J exp. Path., 34, 583.

- Squire, J. R., and Topley, E. (1948). Lancet, 2, 989

Cruickshank, R. (1935). J. Path. Bact., 41, 367.

Davis, A., Ramsay, A. M., and Mann, A. J. (1958). Brit. med. J., $2,1394$.

Dubos, R. J. (1955). Lancet, $2,1$.

Dunbar, J. (1934). Glasg. med. J., $122,239$.

Dupuytren, Baron (1833). Lond. med. surg. J., 3, 806.

Dutton, A. A. C., and Elmes, P. C. (1959). Brit. med. J., 1, 1144

Fabricius, H. (1607). De Combustionibus. Basle.

Fox, J. E., and Lowbury, E. J. L. (1953a). J. Path. Bact., 65, 519. Ter (1953b). Ibid., 65, 533.

eggie, R. M., and Heggie, J. F. (1942). Lancet, 2, 664

Holman, S. P., Shaya, E. S., Hoffmeister, F. S., and Edgerton M. T. (1956). Ann. Surg., 143, 49.

Jackson, D. M. (1951). Brit. med. J., 1, 72

— Lowbury, E. J. L., and Topley, E.'(1951a). Lancet, 2, 705

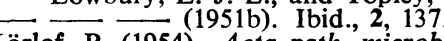

Körlof, B. (1954). Acta path. microbiol. scand., 35, 402

- (1956). Acta chir. scand., Suppl. 209.

Langohr, J. L., Owen, C. R., and Cope, O. (1947). Avn. Surg., 125,452 .

Lawrence, J. C. (1958). Ph.D. Thesis, University of Birmingham. (1959). Brit. J. exp. Path., 40, 8.

Liedberg, N. C. F., Reiss, E., and Artz, C. P. (1954). Surg. Gynec. Obstet., 99,151 . (1955) Kuhn, L. R., Amspacher, W. H., and Artz, C. P

Lister, J. (1909). Collected Papers. Clarendon Press, Oxford.

Lowbury, E. J. L. (1951). J. clin. Path., 4, 66.

- (1954). Lancet, 1, 292.

(1955). Brit. med. J., 1, 985

(1957). Bancet, 2, 305.

(1958). Proc. roy. Soc. Med., 51, 807.

and Cason, J. S. (1954). Brit. med. J., 2, 914

and Collins, A. G. (1955). J. clin. Path., 8, 47

Crockett, D. J., and Jackson, D. M. (1954), Lancet, 2, 1151

and Fox, J. (1954). J. Hyg. (Lond.), 52, 403.

and Lilly, H. A. (1958a). Ibid., 56, 169.

(1958b). Brit. med. J., 2, 1334

and Ricketts, C. R. (1957). J. Hyg. (Lond.), 55, 266

Topley, E., and Hood, A. M. (1952). Lancet, 1, 1036

Lustgarten, S. (1891). Wien. klin. W schr., 4, 528.

McKissock, W., Wright, J., and Miles, A. A. (1941). Brit. med. J., 2, 375.

Markley, K., Gurmendi, G., Chavez, P. M., and Bazan, A. (1957). Ann. Surg., 145, 175.

Marsh, F. (1935). Lancet, 2, 1088. 
Maylard, A. E. (1892). Glasg. med. J., 37, 1

Meleney, F. L. (1948). Treatise on Surgical Infections. Oxford Univ. Press, New York.

Pack, G. T. (1926). Arch. Path. Lab. Med., 1, 767.

Pillemer, L., Blum, L., Lepow, I. H., Ross, O. A., Todd, E. W., and Wardlaw, A. C. (1954). Science, 120, 279

Pirrie, W. (1867). Lancet, 2, 575.

Report of Coli-Aerogenes Sub-committee of the Society of Applied Bacteriology (1956). J. appl. Bact., 19, 108.

Rosenthal, S. M., Millican, R. C., and Rust, J. (1957). Proc. Soc. exp. Biol. (N.Y.), 94, 214 .

Ross, W. P. D. (1950). Brit. J. plast. Surg., 2, 233.

Sevitt, S. (1945). J. Hyg. (Lond.), 44. 37.

Stockis, E. (1903). Arch. int. Pharmacodyn. 11, 201

Thomas, C. G. A., and Hare, R. (1954). J. clin. Path., 7, 300

Wallace, A. B. (1949). Brit. J. plast. Surg., 1, 232.

Wardlaw, A. C., and Pillemer, L. (1956). J. exp. Med., 103, 553.

Weiner, W., and Topley, E. (1955). J. clin. Path., 8, 324.

Willers, J. M. N. (1958). Een Onderzoek Naarde betekenis van properdine voor de naturlijke immuniteit. Utrecht.

Williams, R. E. O., Clayton-Cooper, B., Faulkner, H. C., and Thomas, H. E.'(1944). Lancet, 1, 787.

Wilson, W. C., Macgregor, A. R., and Stewart, C. P. (1938). Brit. J. Surg., 25, 826 .

\section{ACUTE ISCHAEMIA IN LIMB INJURIES}

BY

\section{E. G. HARDY, M.D., F.R.C.S., F.R.C.S.Ed.}

AND

\section{J. TIBBS, M.C., M.S., F.R.C.S.}

From the Department of Surgery, King's College, and the Professorial Surgical Unit, Royal Victoria Infirmary,

$$
\text { Newcastle upon Tyne }
$$

During the Korean war many injured limbs in which the main artery was damaged were restored to good function by the use of modern arterial techniques (Jahnke and Howard, 1953 ; Hughes, 1955). Correspondingly good results might be hoped for in comparable civilian injuries similarly treated. It is disappointing, therefore, that of nine such patients admitted recently to this unit attempts to save the injured limb failed in no fewer than six.

It is proposed to give a brief account of our experience, to study the causes of failure, and to make tentative recommendations for the management of such cases in the future.

\section{Case 1}

A 33-year-old man was admitted to hospital with a simple fracture of the left femoral shaft. It appears that at first the existence of circulatory impairment was missed and conservative treatment of the fracture was begun. Eight hours after admission it was realized that severe ischaemia was present in the distal part of the limb, and manipulation under anaesthesia was performed; the foot, however, remained cold and pulseless.

The patient was transferred to this unit and was operated on about 11 hours after injury. A 2-cm. segment of popliteal artery just below the adductor hiatus was found to be occluded completely by bruising and thrombosis. Resection of the segment with end-to-end anastomosis led to restoration of distal pulses. The fracture was fixed with a Küntscher nail. Next day there was gross swelling of the leg and foot, and fasciotomy was performed. The foot, though swollen, stayed warm and retained palpable pulses until the seventh day, when sudden complete ischaemia developed. Arteriography showed that the block was well below the popliteal bifurcation. Gangrene of the foot ensued, and below-knee amputation was performed on the fifteenth day. Though the posterior tibial artery was pulsatile at the level of amputation, the leg muscles showed extensive aseptic necrosis above this point. Convalescence was slow owing to delayed healing of the stump.
Comment.-Restoration of the circulation failed to reverse the damage done by more than 12 hours of ischaemia, so that extensive necrosis of muscle and late peripheral thrombosis ensued.

\section{Case 2}

A 56-year-old man caught his right arm in a moving belt, sustaining crushing in the elbow region, without fracture. He was seen soon afterwards in a local hospital, where occlusion of the brachial artery was diagnosed, and he was transferred without delay to this unit. Examination here showed that the elbow region was grossly bruised, the forearm and hand were white, pulseless, and numb, and contracture was present in the thenar muscles. At operation, six hours after injury, a $4-\mathrm{cm}$. segment of the brachial artery at the elbow was found to be occluded by bruising and thrombosis. The median nerve was anatomically intact. After excision and homograft replacement of the segment normal circulation was restored. Oedema of the forearm and hand ensued and persisted for several days. On recovery from the anaesthetic he was found to have a median-nerve palsy which took some months to resolve.

Comment.-Restoration of the circulation within eight hours was rewarded by the saving of a limb in which ischaemic contracture would have been inevitable and gangrene probable.

\section{Case 3}

An 82-year-old widow was admitted to hospital with a dislocated right shoulder. The right hand was ischaemic The dislocation was reduced without anaesthesia, whereupon a large haematoma developed in the shoulder region. Thereafter the circulation in the hand was thought to have improved a little, though the radial pulse remained absent. Next day the ischaemic changes were more severe. The distal forearm and hand were pale, cold, and numb; the fingers were cyanotic, and severe contracture was present.

She was transferred to this unit 28 hours after admission, and was soon operated on. The axillary artery was found to be torn half-way across owing to avulsion of the posterior circumflex humeral branch, and was stretched over a large clotted haematoma. The involved segment was resected and a short homograft inserted. Good pulsation returned in the brachial artery down to the elbow, but the hand and distal half of the forearm remained ischaemic. Next morning arteriotomies were made at the wrist and at the elbow, and long string-like thrombi were washed out of the ulnar and radial arteries by the retrograde flush technique (Crawford and DeBakey, 1956). After this there was good circulation down to the wrist ; the hand as far as the roots of the fingers was warm, but showed gross damage with vesication and discoloration; the fingers were gangrenous. The patient was treated conservatively with a view to limited amputation later. After about one week mental and physical deterioration started, and she died $\mathbf{1 5}$ days after the second operation.

Comment.-The circulation was reopened too late to prevent extensive ischaemic damage. Earlier repair of the artery might have saved the limb and the patient's life. In retrospect, amputation through the forearm should have been performed at the time of the first or second operation.

\section{Case 4}

A 21-year-old man was admitted to hospital with a compound fracture of the shaft of the right humerus. At operation extensive flaying of skin and crushing of muscle was noted, and the ulnar nerve was found to be severed. The brachial artery was thought to be in spasm, and attempts were made to restore circulation by applying papaverine to it. Next morning ischaemia of the hand remained complete, and there was severe contracture of the forearm muscles.

The patient was transferred to this unit and operated on approximately 12 hours after the accident. It was found 